\title{
Performances Analysis on Power Quality Problems Mitigation by using Unified Power Quality Conditioner (UPQC)
}

\author{
May Phone Thit \\ Department of Electrical Power \\ Engineering \\ Yangn Technological University \\ Yangon, Myanmar \\ mayphonethit@gmail.com
}

\author{
Soe Soe Ei Aung \\ Department of Electrical Power \\ Engineering \\ Yangn Technological University \\ Yangon, Myanmar \\ soesoeeiaung80@gmail.com
}

\author{
Han Su Yin \\ Department of Electrical Power \\ Engineering \\ Yangn Technological University \\ Yangon, Myanmar \\ hansuyin2009@gmail.com
}

\begin{abstract}
Nowadays, power quality is one of the major problems in electric power distribution system. The poor power quality at distribution level can affect the operation and performance of sensitive and critical loads. In the distribution systems, poor power quality results in various problems such as higher power losses, harmonics, sag and swells in the voltage, and poor power factor., etc. Unified Power Quality Conditioner (UPQC) is the only versatile device which can mitigate several power quality problems related with distribution system. A UPQC that combines the operations of a Distribution Static Compensator (D-STATCOM) and Dynamic Voltage Restorer (DVR) together with the shunt and series active control devices. UPQC can solve the problems related to the voltage/current harmonics, voltage sag/swell and unbalance in distribution system. To evaluate the performance improvement in the system, a model of UPQC is developed in MATLAB/SIMULINK with a typical distribution network. In this research, UPQC is applied for power quality enhancement of Myaungtagar industrial distribution substation, Myanmar. Enhancements in power quality by UPQC are evaluated under maximum load condition. With the application of UPQC, the system voltage and current harmonics are significantly reduced. The reactive power of the system is well compensated and thus system voltage is improved to nearly nominal value.
\end{abstract}

Keywords-Power Quality, UPQC, Series Controller, Shunt controller, Harmonics

\section{INTRODUCTION}

Power quality (PQ) is generally used to assess and to maintain the good power quality at the level of generation, transmission, distribution, and utilization of AC electrical power. Since the poor electric power supply systems can cause too much severe at the utilization level, it is important to study at the terminals of end users in distribution systems. The developments of electronics, electrical device and appliances have become more and more modernized and complex, and they demand unified and conditioned power. These devices can cause the deregulation the present complex electricity network and market in a strong competition result. The operation of these loads and equipments generates harmonics and thus, pollutes the modern distribution system [1].

The supply power quality is essential in any power network particularly to electricity consumers. The heavy consumption of reactive power can cause the poor power quality. The power quality problems affect the customers in a number of ways such as economic penalty in terms of power loss, equipment failure, mal-function, interruption in the process, and loss of production [2]. The main objective of electric distribution is to provide their customers an uninterrupted sinusoidal voltage of constant magnitude and frequency with sinusoidal balanced currents at the AC mains. However, Nowadays, distribution systems are facing severe power quality problems such as high reactive power burden, unbalanced loads and harmonic-rich load currents. In addition, these utilities are not able to avoid the voltage sag, swell, surges, flicker, unbalance, and harmonics in the supply voltages across the consumers' load end [3].

\section{TEChNIQUES FOR POWER QUALITY PROBLEM Mitigation IN DISTRIBUTION SYSTEM}

The power quality problems cause failure of capacitor banks, increased losses in the distribution system and electric machines, noise, vibrations, over voltages and excessive current due to resonance, negative sequence currents in generators and motors, especially rotor heating, derating of cables, dielectric breakdown, interference with communication systems, signal interference, relay and breaker malfunctions, false metering, interferences to the motor controllers and digital controllers, and so on. Thus, power quality problems must be mitigated. [4]

Among the power quality problems, reactive power compensation for voltage regulation, voltage sag and swell, harmonic are considered in this research.

The reactive power compensation improves the stability of ac system by increasing the maximum active power that can be transmitted. The reactive power compensation methods are (i) Series Compensation, (ii) Shunt Compensation, (iii) Synchronous Condenser, (iv) Static VAR Compensator, (v) Distribution Static Synchronous Compensator., etc. The power system improving performance have different solutions, as well as the immunity of the equipment, are described. Mitigation methods for voltage sag and swell are DVR (Dynamic Voltage Restorer), UPS (Uninterruptible Power Supply), D-STATCOM (Distribution Static Synchronous Compensator),, etc. Harmonic mitigation techniques have three categories such as passive techniques, active techniques, and hybrid harmonic reduction techniques.

\section{UNIFIED POWER QUALITY CONDITIONER (UPQC)}

The UPQC is the combination of a series active power filter and shunt active power filter with a common DC link [5]. UPQC is employed in a power distribution system means at 
substation side to perform the shunt and series compensation simultaneously [6]. It is a versatile device for mitigating the multiple power quality problems of voltages and currents. The UPQC is consists of two voltage source converters (VSCs) or current source converters (CSCs) joined back to back by a common DC link capacitor or an inductor at the DC bus, respectively. D-STATCOM (distribution compensator) is known as the shunt device of the UPQC which provides reactive power compensation, load balancing, neutral current compensation, and elimination of harmonics, and it is connected in parallel to the consumer load. The series device of the UPQC, also known as a DVR (dynamic voltage restorer), keeps the consumer load end voltages insensitive to the supply voltage quality problems such as sag/swell, surges, spikes, notches, fluctuations, depression, and unbalance. The DVR injects a compensating voltage between the supply and the consumer load, and restores the load voltage to its reference value [3].

The main purpose of a UPQC is to compensate for voltage/current harmonics, voltage sag/swell and unbalance in distribution system. UPQC has the improving power quality at the point of installation on power distribution systems or industrial power systems. In this research, UPQC is emphasized for mitigation of all quality problems.

\section{A. Construction of UPQC}

The major parts of a UPQC are series active power filter, shunt active power filter, capacitors, inductance filters, series transformers as shown in Fig. 1.

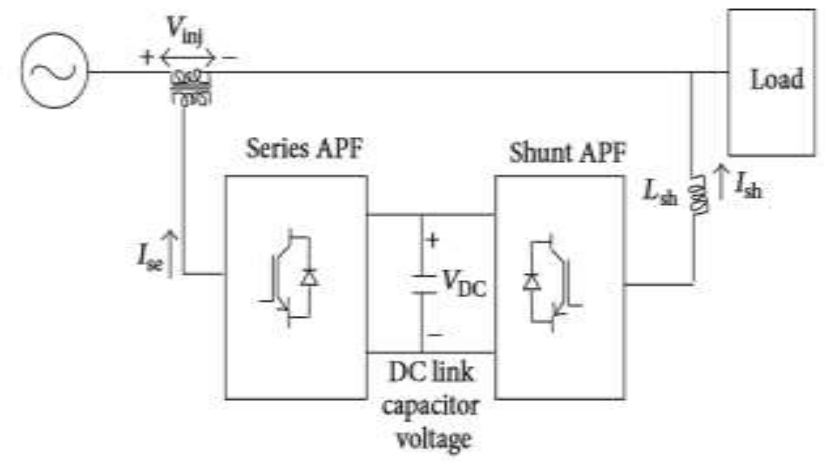

Fig. 1. Unified Power Quality Conditioner (UPQC)

\section{a) Shunt active power filter}

A shunt connected voltage source inverter acts as shunt active power filter. It can help in cancellation of current distortions which compensates the harmonic current of the load. It also provides assistance in keeping up a steady value for the DC link capacitor voltage and also helps in improvement of system power factor. Furthermore, it can help in compensation of load reactive current. Usually hysteresis band controller is applied for controlling of the shunt inverter output current. By adjusting the semiconductor switches reference current can be made to follow the output current and stays within the particular hysteresis band[7].

\section{b) Series active power filter}

A series active power filter is a series connected VSC (voltage-source converter) acting as a source of voltage. It is connected in series with the line by using a series transformer.
It can mitigate the voltage based distortions. It is helpful in maintaining a sinusoidal load voltage by eliminating the load voltage imbalances and the flickers in the terminal voltage. Pulse width modulation (PWM) techniques are used for controlling the series inverter. Mostly hysteresis band technique of pulse width modulation is used. It provides a better and faster response speed, easy to implement and it can work properly even without having the knowledge about the parameters of the system [7].

\section{c) DC link capacitor:}

It is used for back to back connection of the series and shunt VSCs. The DC voltage developed across the capacitor acts as a constant voltage and helps in proper operation of both shunt and series inverters. If regulated properly the voltage provided by this capacitor can be used a source for both active and reactive power and the use of any outer DC source e.g. battery etc. can be eliminated [7].

d) Inductance filter:

It is placed near the series inverter output of UPQC. Acting as a low-pass filter (LPF), it is helpful in attenuation of high-frequency voltage components of the output voltage of the series inverter [7].

\section{e) Series transformer:}

The series converter generates a sinusoidal voltage at a particular required value for maintenance of load voltage. Series inverter support in injection of this voltage through the series transformer. This is need to maintain a particular turn's ratio in order to maintain a low current flow through the series inverter [7].

\section{B. Operation of UPQC}

UPQC is a power electronic device which consists of two voltage source converters (VSC) connected through a common dc-link capacitor. It is used to mitigate both load current and supply voltage unbalanced. A UPQC that combines the operations of a Distribution Static Compensator (D-STATCOM) and Dynamic Voltage Restorer (DVR) together.

Dynamic Voltage Restorer (DVR) is series part of UPQC and it is used to maintain constant and balanced voltage at the load. The series compensator injects a voltage, in such a way that the voltage at the load end remains constant by any voltage disturbance.

If the supply voltage is sag, series converter injects suitable voltage to supply. The following equation represents the series inverter of the UPQC injects a voltage.

$$
\mathrm{V}_{\mathrm{c}}=\mathrm{V}_{1}-\mathrm{V}_{\mathrm{s}}
$$

Where $V_{c}=$ series inverter voltage,

$\mathrm{V}_{1}=$ reference load voltage and

$\mathrm{V}_{\mathrm{s}}=$ actual source voltage respectively.

The D-STATCOM is shunt part of the UPQC and it can compensate load current harmonics, unbalances and power factor correction. It maintains the constant power factor correction. It maintains the constant voltage across the dc link. The shunt compensator consists of a voltage source inverter. The DC side of this voltage source inverter is 
connected to the DC link and the AC side of this inverter is connected to the load though the shunt coupling transformer.

In order to cancel the harmonics generated by a nonlinear load, the shunt inverter should inject a current given by the following equation.

$\mathrm{Ic}=\mathrm{I}_{1}-\mathrm{I}_{s}$

Where $I_{c}=$ shunt inverter current,

$\mathrm{I}_{1}=$ reference load current and ,

$\mathrm{I}_{\mathrm{s}}=$ actual source current respectively.

UPQC can improve the power quality by preventing load current harmonics. The main purpose of the UPQC is to compensate for supply voltage power quality issues such as voltage sag, swell, unbalance and flicker. During voltage sag and swell conditions, the DC link supplies required voltage for the compensation. The inverter circuit in UPQC will convert the $\mathrm{DC}$ voltage to $\mathrm{AC}$ voltage. The inverters will generate the harmonics. The harmonics generated by these inverters are filtered by using active filters [8].

For reactive power compensation, D-STATCOM is used. DVR is used for voltage sag and swell. These problems are mitigated by UPQC (unified power quality conditioner). UPQC is emphasized in this research because it gives the effectiveness of power quality problems mitigation.

\section{INDUSTRIAL DISTRIBUTION SYSTEM UNDER STUDY}

In this research, the case study area is chosen at Myaungtagar industrial distribution zone, Myanmar. It has seventeen feeders. Eight feeders are connected with $230 \mathrm{kV} / 33 \mathrm{kV} 100 \mathrm{MVA}$ step-down transformer, five feeders are connected with $230 \mathrm{kV} / 33 \mathrm{kV}$ 60MVA step-down transformer, and four feeders are connected with $230 \mathrm{kV} / 33 \mathrm{kV}$ 150MVA transformer respectively. This research is emphasized on 100MVA transformer side in which the power quality problem occurs due to industrial loads such as steel mill loads. The single line diagram of case study area is shown in Fig. 2. and Fig. 3. shows the maximum demand power of eight feeders of $100 \mathrm{MVA}$ side for a typical day. The names of the feeders are Zone 1, Zone 2, Zone 3, Zone 4, Zone 5, Zone 5, Zone 6, Fertilizer 1, and Fertilizer 2 respectively.

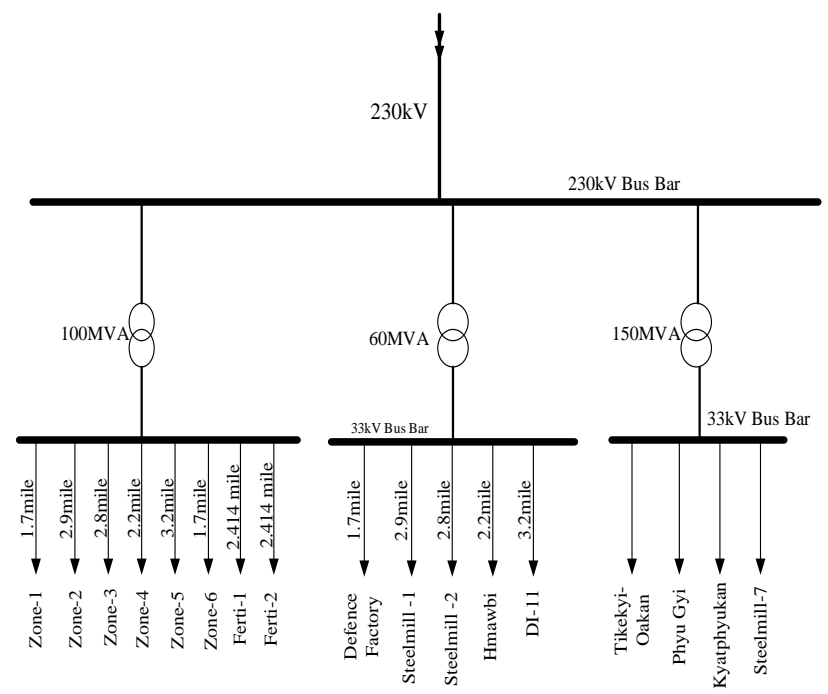

Fig. 2. Single Line Diagram of Myaungtagar Substation
The system parameters of the case study area such as system frequency, source voltage, transformer ratings are as shown in Table 1. Load demands for the existing system are tabulated in Table 2. These data are collected on May,2018. These load demand are maximum demand base on May,2018 data. In this table, line length of each feeder, linear load and non-linear load of active power and reactive power consumptions for each feeder are described.

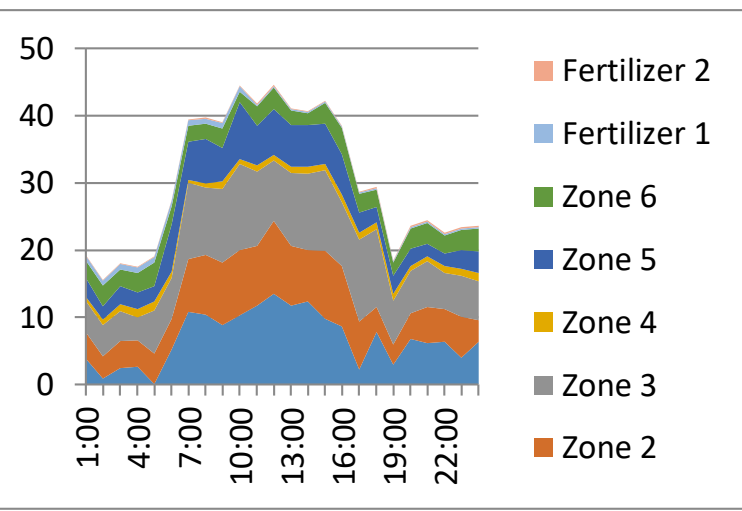

Fig. 3. Demand Power of Eight Feeders for a Typical Day

TABLE I. SySTEM PARAMETERS OF THE CASE STUDy AREA

\begin{tabular}{|l|l|}
\hline Parameters & Values \\
\hline Source Voltage & $230 \mathrm{kV}$ \\
\hline Distribution Voltage & $33 \mathrm{kV}$ \\
\hline System Frequency & $50 \mathrm{~Hz}$ \\
\hline Transformer Primary Voltage & $230 \mathrm{kV}$ \\
\hline Transformer Secondary Voltage & $33 \mathrm{kV}$ \\
\hline Transformer Capacity & $100 \mathrm{MVA}$ \\
\hline
\end{tabular}

TABLE II. LOAD DEMAND FOR SIMULINK MODEL OF EXISTING SYSTEM

\begin{tabular}{|l|c|c|c|c|c|}
\hline \multirow{2}{*}{ Feeders } & \multirow{2}{*}{$\begin{array}{l}\text { Length } \\
(\mathbf{k m})\end{array}$} & \multicolumn{2}{l|}{ Linear Load } & \multicolumn{2}{l|}{ Non-Linear Load } \\
\cline { 3 - 6 } & & $\boldsymbol{P}$ & $\begin{array}{c}\boldsymbol{Q} \\
(\boldsymbol{M} \boldsymbol{V} \boldsymbol{A} \boldsymbol{R})\end{array}$ & $\begin{array}{c}\boldsymbol{P} \\
(\boldsymbol{M W})\end{array}$ & $\begin{array}{c}\boldsymbol{Q} \\
(\boldsymbol{M V A R})\end{array}$ \\
\hline Zone 1 & 2.736 & 7.14 & 4.425 & 4.76 & 2.950 \\
\hline Zone 2 & 4.667 & 4.32 & 2.676 & 2.88 & 1.784 \\
\hline Zone 3 & 4.506 & 8.76 & 5.429 & 5.84 & 3.619 \\
\hline Zone 4 & 3.541 & 11.4 & 7.065 & 7.6 & 4.710 \\
\hline Zone 5 & 5.150 & 5.46 & 3.383 & 3.64 & 2.256 \\
\hline Zone 6 & 2.736 & 3.12 & 1.932 & 2.08 & 1.288 \\
\hline Ferti 1 & 2.414 & 2.64 & 1.636 & 1.76 & 1.090 \\
\hline Ferti 2 & 2.414 & 5.16 & 3.197 & 3.44 & 2.132 \\
\hline
\end{tabular}

\section{A. Design Calculation of D-STATCOM Parameter}

Table 3. INPUT PARAMETERS FOR DESIGN CALCULATION OF DVR AND D-STATCOM FOR UPQC

\begin{tabular}{|l|l|l|l|}
\hline No: & Parameters & Values & Unit \\
\hline 1 & Modulation index $(\mathrm{m})$ & 1 & - \\
\hline 2 & Line Voltage, $\mathrm{V}_{\mathrm{LL}}$ & $33 \times 10^{3}$ & $\mathrm{~V}$ \\
\hline 3 & $\begin{array}{l}\text { Variation of energy during dynamics } \\
\left(\mathrm{k}_{1}\right)\end{array}$ & $10 \%$ & - \\
\hline
\end{tabular}




\begin{tabular}{|l|l|l|l|}
\hline 4 & Overloading factor, $\alpha$ & 1.2 & \\
\hline 5 & DC bus recovered time, $\mathrm{t}$ & 30 & $\mathrm{~ms}$ \\
\hline 6 & Current Ripple, $\mathrm{I}_{\text {crpp }}, \mathrm{f}_{\mathrm{s}}$ & $15 \%$ & - \\
\hline 7 & Switching frequency & 2000 & $\mathrm{~Hz}$ \\
\hline
\end{tabular}

Table 3. describe the input parameters for design calculation of DVR and D-STATCOM for UPQC.

\section{a) Selection of the DC Bus Voltage}

The minimum DC bus voltage of the VSC of the DSTATCOM should be greater than twice of the peak of the phase voltage of the distribution system. The DC bus voltage is calculated as

$$
\mathrm{V}_{\mathrm{DC}}=\frac{2 \sqrt{2} \mathrm{~V}_{\mathrm{LL}}}{\sqrt{3} \mathrm{~m}}
$$

where $\mathrm{m}$ is the modulation index and is considered as 1 and $\mathrm{V}_{\mathrm{LL}}$ is the AC line output voltage of the D-STATCOM.

$$
\mathrm{V}_{\mathrm{DC}}=53.889 \mathrm{kV}
$$

Thus, $\mathrm{V}_{\mathrm{DC}}$ is obtained as $53.889 \mathrm{kV}$ for a $\mathrm{V}_{\mathrm{LL}}$ of $33 \mathrm{kV}$ and it is selected as $54 \mathrm{kV}$.

\section{b) Selection of a DC Bus Capacitor}

The value of the DC capacitor $\left(\mathrm{C}_{\mathrm{DC}}\right)$ of the VSC of the D-STATCOM depends on the instantaneous energy available to the D-STATCOM during transients. The principle of energy conservation is applied as

$$
\frac{1}{2} \mathrm{C}_{\mathrm{DC}}\left(\mathrm{V}_{\mathrm{DC}}^{2}-\mathrm{V}_{\mathrm{DC} 1}^{2}\right)=k_{1} 3 V \alpha I t
$$

where $; \mathrm{V}_{\mathrm{DC}}=$ the nominal $\mathrm{DC}$ voltage equal to the reference DC voltage

$\mathrm{V}_{\mathrm{DC} 1}=$ the minimum voltage level of the DC bus,

$\alpha=$ the overloading factor

$\mathrm{V}=$ the phase voltage,

$\mathrm{I}=$ the phase current, and

$\mathrm{t}=$ the time by which the DC bus voltage is to be recovered.

$$
\mathrm{C}_{\mathrm{DC}}=5.328 \times 10^{-3} \mathrm{~F}
$$

When $\mathrm{I}=2231.1787 \mathrm{~A}, \mathrm{t}=30 \mathrm{~ms}, \alpha=1.2$, and variation of energy during dynamics $=10 \%\left(\mathrm{k}_{1}=0.1\right)$, the calculated value of $\mathrm{C}_{\mathrm{DC}}$ is $5.328 \times 10^{-3} \mathrm{~F}$. VSC

\section{c) Selection of an AC Inductor for the Phase Leg of the}

The selection of the AC inductance $\left(\mathrm{L}_{\mathrm{f}}\right)$ of a VSC depends on the current ripple, $I_{\text {cr,pp}}$, switching frequency $f_{s}$, and $\mathrm{DC}$ bus voltage $\left(\mathrm{V}_{\mathrm{DC}}\right)$, and it is given as

Considering Icr,pp $=15 \%, \mathrm{f}_{\mathrm{s}}=2000 \mathrm{~Hz}, \mathrm{~m}=1, \alpha=1.2$

$$
L_{f}=\frac{\sqrt{3} m V_{D C}}{12 \alpha f_{s} I_{c r, p p}}
$$

where $\mathrm{m}$ is the modulation index and $\alpha$ is the overloading factor, $\mathrm{f}_{\mathrm{s}}=$ switching frequency, $\mathrm{I}_{\mathrm{cr} . \mathrm{pp}}=$ current ripple; Considering Icr;pp $=15 \%, \mathrm{f}_{\mathrm{s}}=2 \mathrm{kHz}, \mathrm{m}=1, \mathrm{~V}_{\mathrm{DC}}=54 \mathrm{kV}$, and $\alpha=1.2$, the value of $L_{f}$ is calculated to be $9.7037 \mathrm{mH}$.

\section{B. Design Calculation of DVR Parameter}

a) Selection of an Injection Transformer of the DVR

The injection transformer is selected for connecting the VSC of a DVR in series with the supply. The voltage rating of the transformer depends on the voltage to be injected and the DC bus voltage of the VSC. For compensating a voltage variation of $\pm 30 \%$, the voltage to be injected is calculated as

$$
\mathrm{V}_{\mathrm{DVR}}=\mathrm{XV}_{\mathrm{s}}
$$

where; $\mathrm{X}=$ compensation for the voltage variation

b) Turns ratio of the injection transformer for the DVR

The DC bus voltage of $54 \mathrm{kV}$ (decided for $33 \mathrm{kV}$ for the D-STATCOM) can be used to obtain $33 \mathrm{kV}$ across the line at the output of the VSC using a PWM controller. However, the DVR requires only $7.126 \mathrm{kV}$ per phase. Therefore, the maximum value of the turns ratio of the injection transformer is

$$
\mathrm{K}_{\mathrm{DVR}}=\frac{\mathrm{V}_{\mathrm{VSC}}}{\mathrm{V}_{\mathrm{DVR}}}
$$

where; $\mathrm{V}_{\mathrm{VSC}}=$ voltage of voltage source converter $\mathrm{V}_{\mathrm{DVR}}=$ voltage of DVR

$$
\mathrm{K}_{\mathrm{DVR}}=2.6737 \approx 3
$$

c) Capacity of the injection transformer

$$
\mathrm{S}_{\mathrm{DVR}}=3 \mathrm{~V}_{\mathrm{DVR}} \mathrm{I}_{\mathrm{DVR}} \text { (under-sag) }
$$

d) Selection of Interfacing Inductors of the DVR

The current through the secondary side of the injection transformer is decided by real power of the load. The minimum supply current occurs during voltage swell. The minimum value of supply current is

$$
\mathrm{I}_{\text {DVR(under-swell) }}=\frac{\mathrm{P}_{\mathrm{L}}}{3(1+\mathrm{X}) \mathrm{V}_{\mathrm{ph}}}
$$

Considering a $10 \%$ ripple in supply current, the value of filter inductance of the DVR is given as

$$
\mathrm{L}_{\mathrm{DVR}}=\frac{\frac{\sqrt{3}}{2} \mathrm{~m}_{\mathrm{a}} \mathrm{V}_{\mathrm{DC}} \mathrm{K}_{\mathrm{DVR}}}{6 \alpha \mathrm{f}_{\mathrm{s}} \Delta \mathrm{I}_{\mathrm{DVR}}}
$$

The output results are get from the design calculation of DVR and D-STATCOM by using the above equations and that is tabulated in Table 4.

Table 4. Output Parameters for Simulation Model of UPQC

\begin{tabular}{|l|c|}
\hline \multicolumn{1}{|c|}{ Parameters } & Values \\
\hline Source Voltage & $230 \mathrm{kV}$ \\
\hline Distribution Voltage & $33 \mathrm{kV}$ \\
\hline System Frequency & $50 \mathrm{~Hz}$ \\
\hline D-STATCOM, Filter Inductance, $\mathrm{L}_{\mathrm{f}}$ & $9.7037 \mathrm{mH}$ \\
\hline DC Link Voltage of Shunt inverter, $\mathrm{V}_{\mathrm{dc}}$ & $54 \mathrm{kV}$ \\
\hline DC Link Capacitor, $\mathrm{C}_{\mathrm{dc}}$ & $5.328 \mathrm{e}-3 \mathrm{~F}$ \\
\hline DVR, Filter Inductance, $\mathrm{L}_{\mathrm{f}}$ & $70.585 \mathrm{mH}$ \\
\hline Turn ratio of Transformer & 3 \\
\hline Capacity of Transformer & $64.767 \mathrm{MVA}$ \\
\hline
\end{tabular}

\section{Modeling of CASE Study Area}

The case study area of the industrial distribution system source voltage $230 \mathrm{kV}$ is connected with $230 \mathrm{kV} / 33 \mathrm{kV}$ step down transformer. The outgoing of the step down transformer 
distribute the voltage for the eight feeders. The system have non-linear load and linear load. The modeling of the existing system without compensation is as shown in Fig. 4.

According to the simulation result, the secondary voltage and current waveform of the existing system without compensation is shown in Fig 5. The voltage and current waveforms are not smooth and sinusoidal because of harmonic distortion when the system doesn't have active power filter.

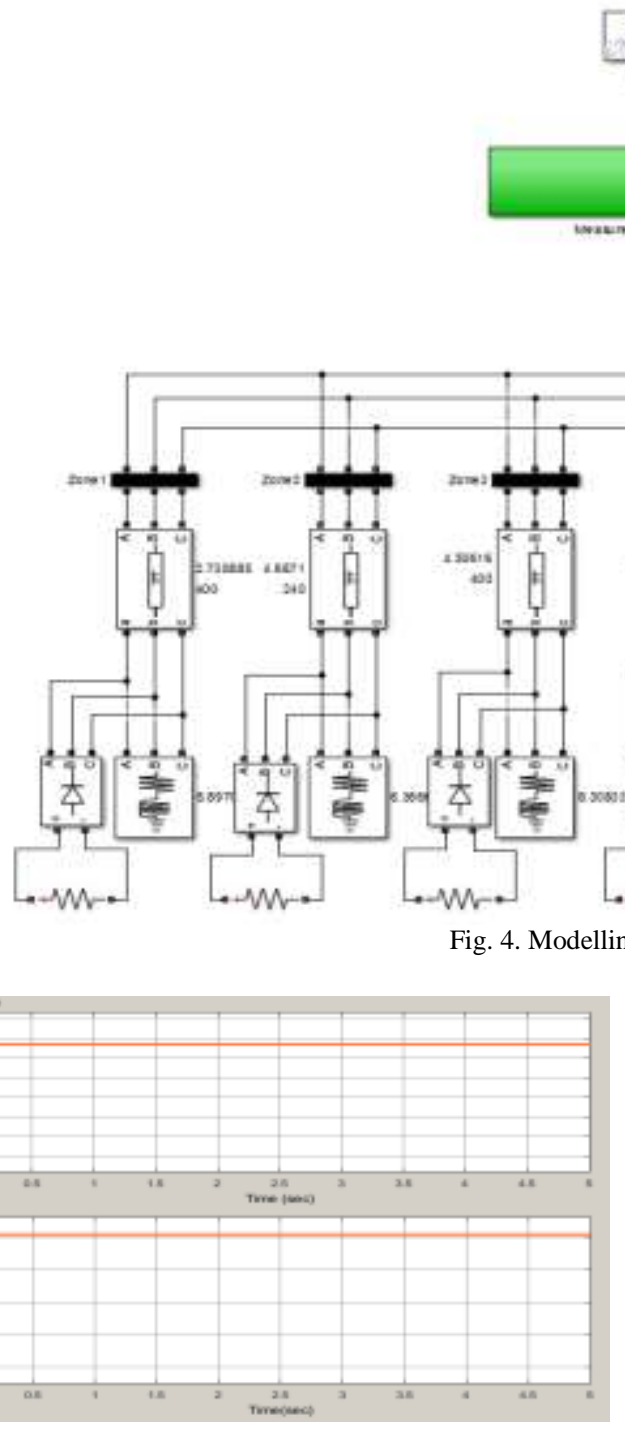

Fig. 5. Voltage and Current Profile of Existing System without Compensation

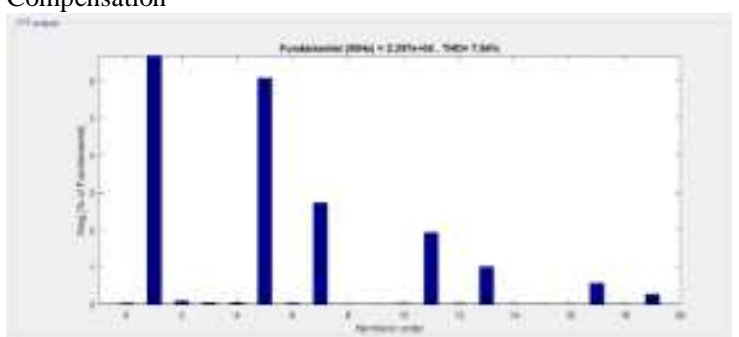

Fig. 6. Voltage Harmonic Profile of Existing System without Compensation

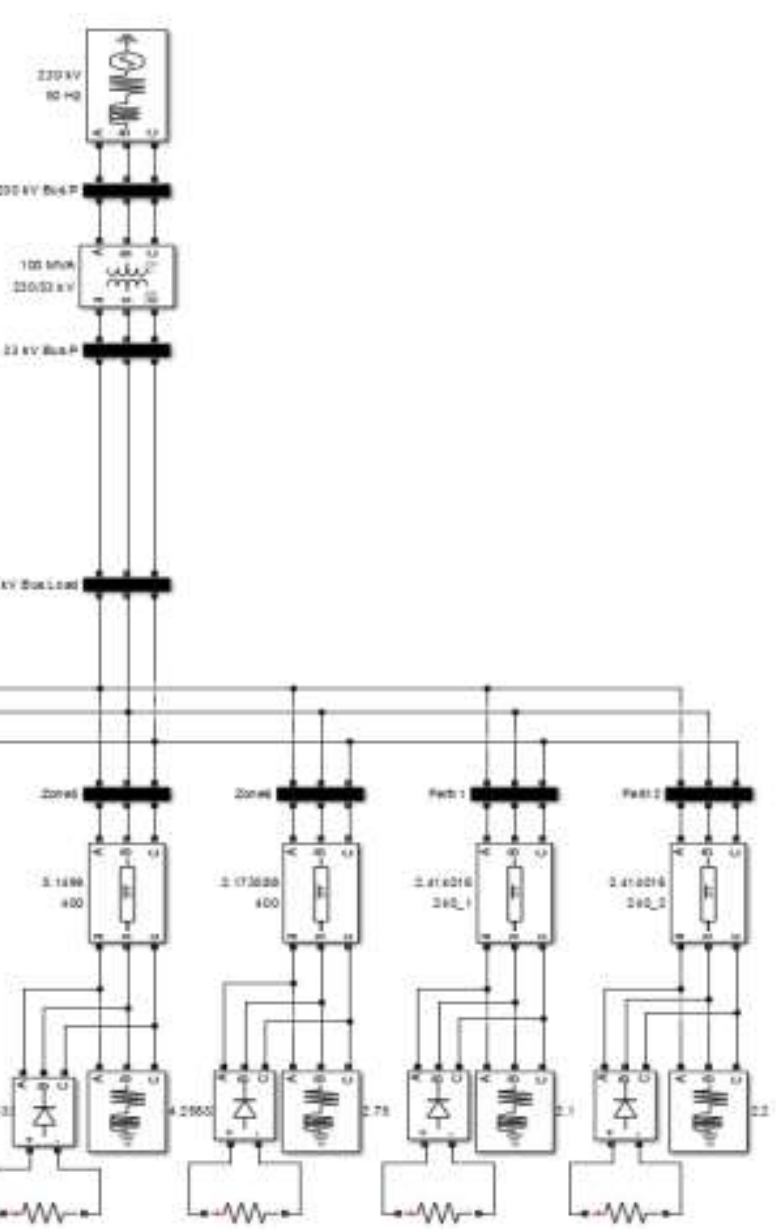

The voltage and current harmonic profiles are shown in Fig 6 and 7. The power factor of the existing system without compensation is as shown in Fig 8.

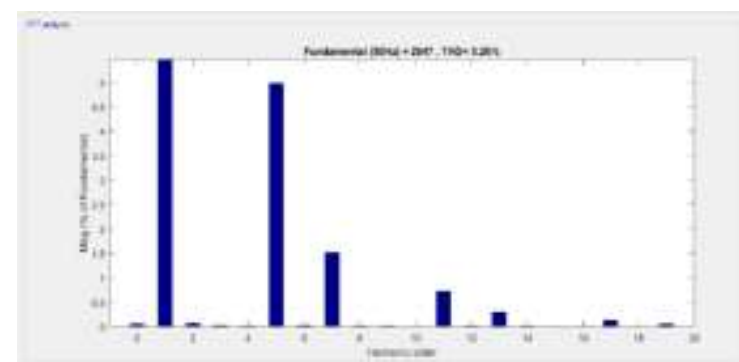

Fig. 7. Current Harmonic Profile of Existing System without Compensation

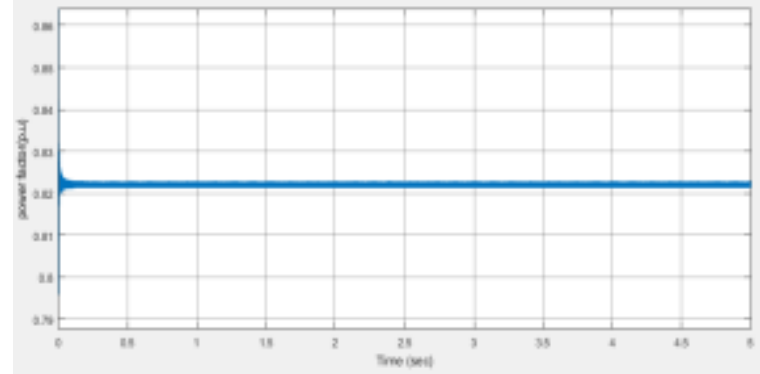

Fig. 8. Power Factor of the Existing System without Compensation 
From the simulation results, the voltage is dropped from $33 \mathrm{kV}$ to $28.56 \mathrm{kV}$. the voltage harmonic distortion is $7.04 \%$ and current harmonic distortion is $5.26 \%$. The voltage regulation is poor such as $13.46 \%$ and power factor is also poor, about 0.82 p.u.

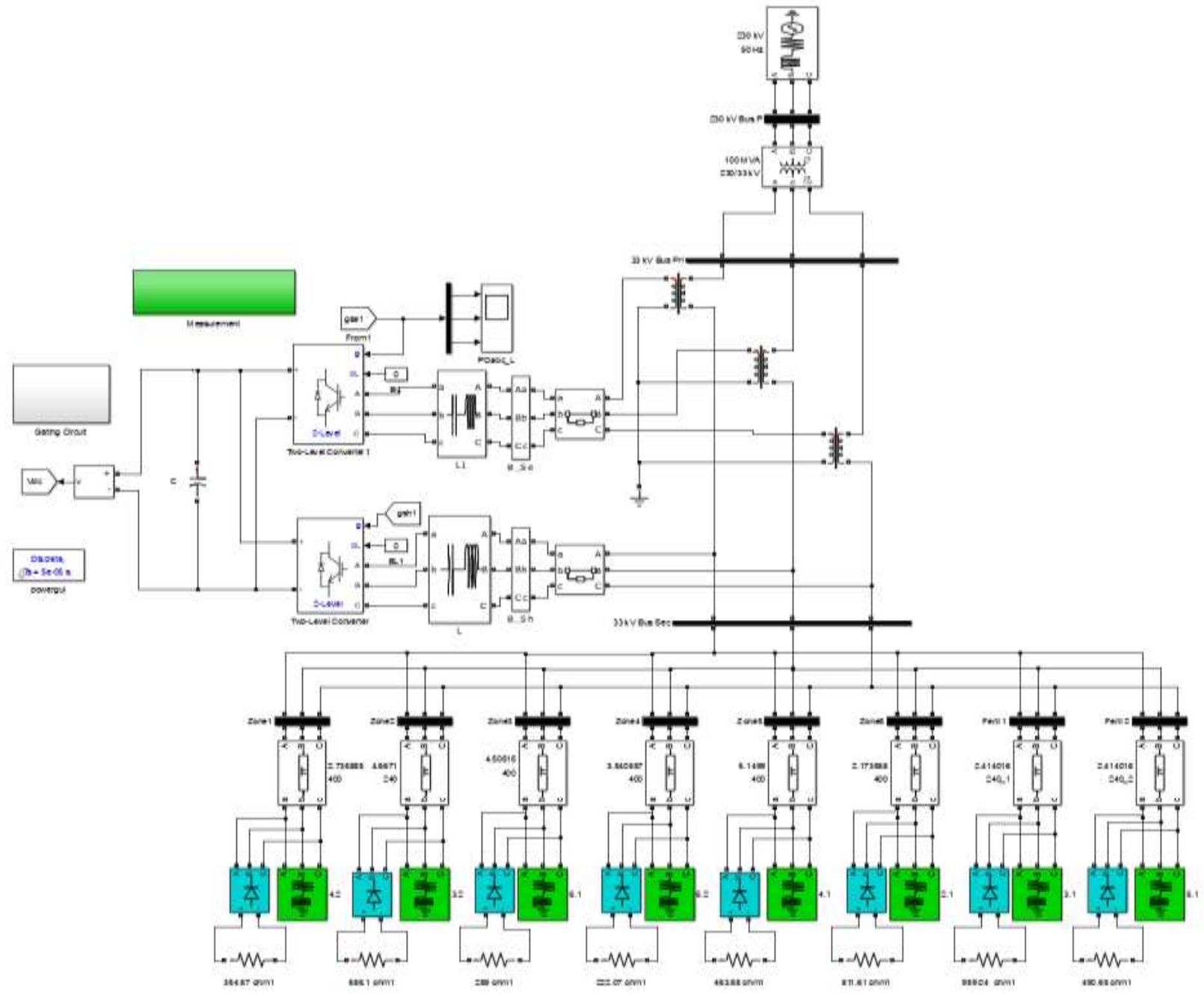

Fig. 9. Modeling of Existing System with UPQC

A. Modelling and Simulation Analysis of the Research Area with UPQC

Power quality is one of the major problems in the today's scenario. Non-linear loads in distribution system, which severely affect the quality of power supplies. The poor power quality at distribution level can affect the operation and performance of sensitive and critical loads. To perform the solution for the power quality problems encountered in distribution system, modelling and simulation of the Unified Power Quality Conditioner (UPQC) is presented in this research.

Analyzing the existing system under normal condition without and with UPQC

Firstly, starting the simulation time for the normal condition is $1.5 \mathrm{sec}$, and then, UPQC is connected after 1.5 sec simulation time. In this way, the system is separated without and with UPQC.

Fig. 9. shows Modeling of Existing System with UPQC. Fig. 10. shows the voltage and current profile of the existing system with and without UPQC. In this result, the voltage profile is obviously improving by using UPQC after $1.5 \mathrm{sec}$ simulation time. Before connecting UPQC, the voltage of the existing is $\mathrm{V}=28.63 \mathrm{kV}$, after connected with UPQC, the voltage profile is $\mathrm{V}=32.55 \mathrm{kV}$.

Active power and reactive power simulation results of the existing system with and without UPQC are as shown in Fig. 11. Although active power profile is not too much

difference without (82.82MW) and with (83.55MW) UPQC, reactive power profile is reduced a lot due to the compensation of UPQC. Existing system of the reactive power is $57.5 \mathrm{MVAR}$. By using UPQC, the reactive power is compensated to 5.674MVAR.

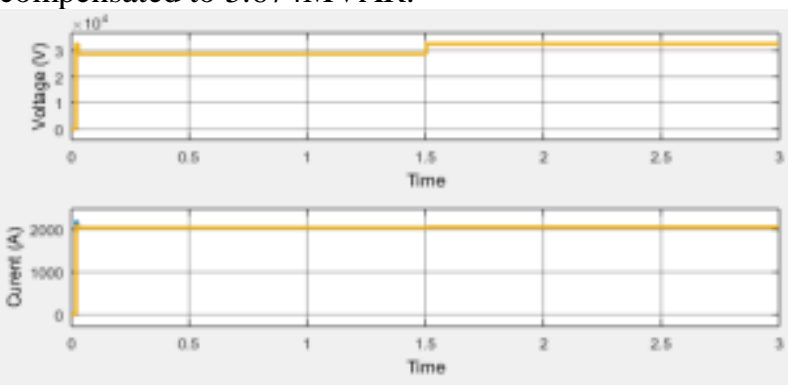

Fig. 10. Voltage and Current Profile of Existing System with and without UPQC 


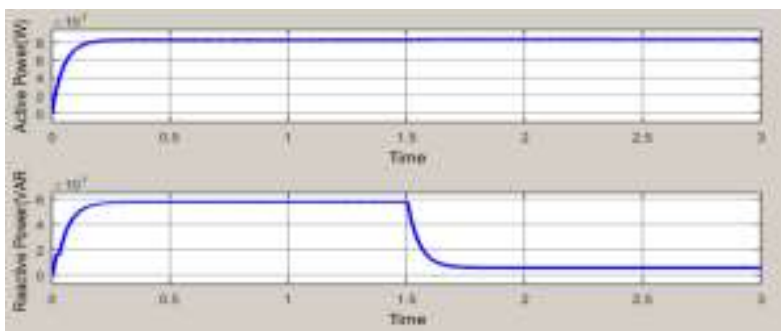

Fig. 11. Active and Reactive Power of the existing with and without UPQC

Power Factor profile of the existing system with and without UPQC describe in Fig. 12. The magnitude of power factor without UPQC of the existing system is 0.822 . After connecting the UPQC at $1.5 \mathrm{sec}$ simulation time in the existing system, the power factor improves to 0.99 p.u.

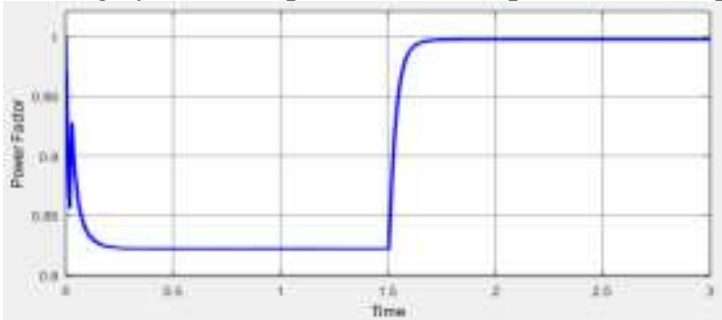

Fig. 12. Power Factor Profile of the Existing System with and without UPQC

Voltage harmonic profile of the existing system with UPQC as shown in Fig. 13. THD \% is $1.29 \%$. This result can accept under the limit of IEEE Standard. Current Harmonic Profile of Existing System with UPQC can be seen at Fig. 14. THD\% of current limit for IEEE Standard is $5 \%$. Therefore, according to simulation result is $1.05 \%$ which is also within the limit.

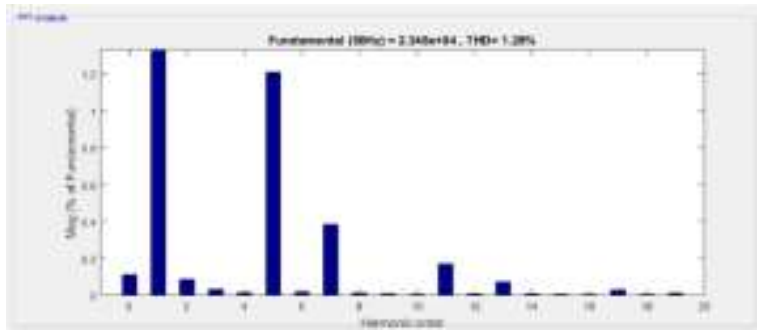

Fig. 13. Voltage Harmonic Profile of Existing System with UPQC

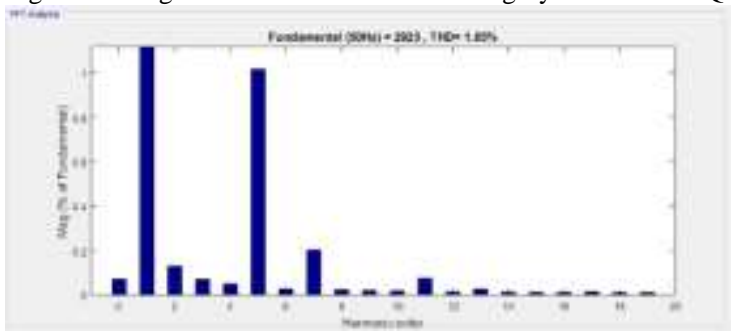

Fig. 14. Current Harmonic Profile of Existing System with UPQC

\section{CONCLUSION}

In this research, Myaungtagar distribution system $(230 / 33 \mathrm{kV})$, Myanmar is chosen as case study area because it has 6 feeders of non-linear load (steel mill factory). So, power quality problem such as harmonics, unbalance, voltage sag and swell conditions occur. UPQC is used to compensate these quality problems by using MATLAB simulation in this research. In case of harmonic, voltage harmonic (\% THD) is reduced from $7.04 \%$ to $1.29 \%$, current harmonic (\%THD) is reduced from $5.26 \%$ to $1.05 \%$ by using the MATLAB simulation with UPQC. By using UPQC, the reactive power in the system is compensated from 57.51MVAR to 5.67MVAR. Therefore, system voltage is improved from $28.63 \mathrm{kV}$ to $32.55 \mathrm{kV}$. Thus, the power factor of the system is improved. So, UPQC is a good power quality enhancing device in the distribution system. Other researcher should improve the performance by using advanced or different control techniques and compare the results with intelligent controller in place of PID controller.

\section{ACKNOWLEDGMENT}

The author would like to express her earnest gratitude to all of her professors, supervisor, and teachers of Electrical Power Engineering Department of the Yangon Technological University and her friends for their guidance, encouragement, and inspiration to complete this research.

\section{REFERENCES}

[1] J.P.Sridhar and Dr.R Prakash, "Power Quality Issues and Its Mitigation by Unified Power Quality Conditioner" Proc. of Int. Conf. on Current Trends in Eng., Science and Technology, ICCTEST, January 2017.

[2] Navneet Kaur and Gagan Deep Yadav, "Power Quality Standards, Problems and their Solutions," International Journal of Trend in Scientific Research and Development (IJTSRD), ISSN No: 2456 - 6470 | www.ijtsrd.com | Volume - 2 | Issue - 1, Nov-Dec 2017.

[3] Bhim Singh, Ambrish Chandra and Kamal Al-Haddad, "Power Quality Problems And Mitigation Techniques,” ISBN: 9781118922057, 2015.

[4] P.Esther Rani, D.Bhavana Rushi and Sk.Rizwana, "Performance Comparison of Shunt Active Power Filter with Different Control Algorithms Using Particle Swarm Optimization," International Journal of Advanced Research in Electrical, Electronics and Instrumentation Engineering (An ISO 3297: 2007 Certified Organization, Vol. 5, Issue 7, July 2016.

[5] Hideaki Fujita, Member, IEEE, and Hirofumi Akagi, Fellow, IEEE, "The Unified Power Quality Conditioner: The Integration of Series- and Shunt-Active Filters," IEEE Trans. On Power Electronics, Vol. 13, no. 2, March 1998.

[6] Vinod Khadkikar, Member, IEEE, "Enhancing Electric Power Quality Using UPQC:A Comprehensive Overview," IEEE Trans. On Power Electronics, vol.27, no. 5, May 2012.

[7] Shrutisnata Mishra, "Power Quality Improvement Using Unified Power Quality Conditioner" Department of Electrical Engineering National Institute of Technology Rourkela, May 2016.

[8] A.S. N. Anjali Devi and G. Madhav, "Unified Power Quality Conditioner In Distribution System for Enhancing Power Quality," International Journal of Electrical Engineering \& Technology (IJEET) Volume 7, Issue 6, Nov-Dec, 2016, pp.55-63, Article ID: IJEET_07_06_005 